\title{
Rabies Antibodies in Vaccinated Dogs
}

\author{
By L. Sihvonen, K. Kulonen, E. Neuvonen and K. Pekkanen
}

National Veterinary and Food Research Institute, Vaccine and Production Unit and Virology Unit, Helsinki, Finland.

\begin{abstract}
Sihvonen, L., K. Kulonen, E. Neuvonen and K. Pekkanen: Rabies antibodies in vaccinated dogs. Acta vet. scand. 1995, 36, 87-91. - Forty-seven healthy, owned dogs were vaccinated with Madivak and 85 with Rabisin. Geometric mean titres of 17.40 and 1.03 $\mathrm{IU} / \mathrm{ml}$ were measured by the rapid immunofluorescent focus inhibition test 30-40 and $350-370$ days, respectively, after a single injection. Four out of $130(3.1 \%)$ and 18 out of $106(17 \%)$ dogs had a titre of less than $0.5 \mathrm{IU} / \mathrm{ml}$ in serum $30-40$ and $350-370$ days after vaccination. Twenty-one dogs $(19.8 \%)$ had a titre of $0.5 \mathrm{IU} / \mathrm{ml} 350-370$ days after vaccinaton. There was no significant difference in antibody levels between animals vaccinated with Rabisin or Madivak. Our results indicate that a booster is always necessary after a single injection to ensure that all dogs have a lasting antibody titre.
\end{abstract}

immunization; protection.

\section{Introduction}

Dogs can introduce rabies into rabies-free countries if they are incubating the disease and are transported during the presymptomatic phase. To prevent such introduction quarantine is compulsory in many countries. Dogs are, however, still important vectors of rabies in many parts of the world, e.g. in South-east Asia (Sage 1993).

Finland has been free of rabies for over 30 years except for an epidemic of sylvatic rabies in southeastern Finland in 1988-1989 (Nyberg et al. 1992). After this rabies outbreak, vaccination of all dogs and cats was strongly recommended throughout the country. Before the epidemic, rabies vaccination was only compulsory for hunting dogs in eastern Finland.

Titres of rabies neutralizing antibodies are an easy way of evaluating the likelihood of a dog not contracting rabies after exposure (Aubert 1993). In our study, we determined how long rabies antibody titres are maintained in healthy, owned dogs after a single vaccination.
The 2 vaccines chosen are widely used inactivated and adjuvated products based on virus produced in cell cultures. The vaccine producers have results of laboratory trials in which dogs developed antibodies and were protected against challenge 3 years after a single vaccination. Vaccine producers recommend booster injection yearly or every 1,2 or 3 years, depending on local regulations.

\section{Materials and methods}

Two commercial rabies vaccines, Madivak and Rabisin, were used for vaccination. Madivak is a commercial inactivated and adjuvated (aluminium hydroxide) vaccine prepared from a Flury low egg passage strain of rabies virus cultivated in chick fibroblast cell cultures. Dogs were vaccinated with Madivak batch no 033A purchased from Hoechst, Germany. Rabisin is a commercial inactivated and adjuvated (aluminium hydroxide) vaccine prepared from rabies virus cultivated in a Nilcell culture (hamster embryo, monolayer cul- 
Table 1. Geometric mean titres (GMT) and rabies antibody range in 132 dogs after vaccination with Rabisin or Madivak.

\begin{tabular}{lccc}
\hline & \multicolumn{3}{c}{ Days after vaccination } \\
\cline { 2 - 4 } & 0 & $30-40$ & $350-370$ \\
\hline GMT (IU/ml) & 0.03 & 17,40 & $1,03^{\mathrm{a}}$ \\
Range(IU/ml) & $0-0.5$ & $0-\geq 121.5$ & $0-\geq 121.5$ \\
Sample size & $125^{\mathrm{b}}$ & $130^{\mathrm{c}}$ & $106^{\mathrm{d}}$ \\
\hline
\end{tabular}

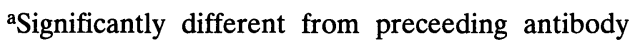
level $(\mathrm{p}<0.0001)$.

${ }^{b} 5, c^{2}$ and ${ }^{d} 26$ sera were not available for testing.

ture). Dogs were vaccinated with Rabisin batches no 60R741, 70P963, 80Y054 and 80 T993 purchased from Rhône-Merieux, Lyons, France.

Dogs were vaccinated by injecting $1 \mathrm{ml}$ of the vaccine subcutaneously. The vaccination was performed and blood samples were taken by 5 veterinary surgeons. Forty-seven dogs were vaccinated with Madivak and 85 with Rabisin. Blood samples were drawn on days $0,30-40$ and 350-370 for rabies antibody determination. Blood samples were not available for testing from all dogs at each collection time (Table 1). Twenty-one dogs were under 1 year and 105 were over 1 year old. The age of 6 dogs was unknown. According to the owners, none of the dogs had previously been vaccinated against rabies. All the dogs were referred for this trial by their veterinary surgeon.

The rabies virus neutralizing antibodies were detected with a modification of the RFFIT test (Smith et al. 1973). Briefly, the sera were titrated on a 96-well microtitre plate in 3-fold dilutions after predilution at 1:10. The sera and the Challenge Virus Strain (rabies virus, WHO, Tubingen, Germany) were incubated at $37^{\circ} \mathrm{C}$ for $90 \mathrm{~min}$, after which BHK cells were added. The cultures were fixed after $24 \mathrm{~h}$ and stained with anti-rabies fluorescent conjugate (Behringwerke, Marburg, Germany). The challenge dose used was the highest dilution of virus giving $40 \%$ infected cells (fluorescent inclusions). Each time the RFFIT was conducted, a WHO reference serum diluted to contain $0.5 \mathrm{IU} / \mathrm{ml}$ of rabies virus neutralizing antibody was used to ensure quality control. The neutralization index was determined as described by Wiktor et al. (1984). Results of $<0.17 \mathrm{IU} / \mathrm{ml}$ were considered negative. The geometric mean titres (GMT) were calculated from $\log _{10}$ transformed data, which were then transformed into international units (IU/ml). Statistical tests were applied on $\log _{10}$ trans. formed values. Paired T test was used to compare antibody levels at different collection times. Two-Sample T Test and AOV + Tukey were used to compare the antibody levels of the Rabisin and Madivak groups.

\section{Results}

GMT values and rabies antibody titres in international units (IU/ml) after a single injection are listed in Tables 1 and 2.On days 30-40 after vaccination, rabies neutralizing antibody titre $(\geq 0.5 \mathrm{IU} / \mathrm{ml})$ was found in 126 out of 130 (96.9\%) dogs. On days 350-370, 88 out of 106 dogs $(83 \%)$ had a rabies antibody titre of $\geq 0.5$ $\mathrm{IU} / \mathrm{ml}$. The titres of 21 of the $88 \mathrm{dogs}$ was 0.5 IU/ml.

There was no significant difference in antibody levels on days 30-40 ( $\mathrm{p}=0.8400)$ and on days $350-370(\mathrm{p}=0.3617)$ between animals vaccinated with Rabisin or Madivak (Table 2 ). There was a statistically significant difference $(\mathrm{p}<0.0001)$ between the antibody levels on days 30-40 and on days 350-370 (Table 1).

\section{Discussion}

Postvaccinal immunity to rabies in animals can be assessed either by performing challenge experiments or by detecting the pres- 
Table 2. Geometric mean titres (GMT) and rabies antibody range in dogs after vaccination with Rabisin (85 dogs) or Madivak (47 dogs).

\begin{tabular}{|c|c|c|c|c|c|c|c|c|c|}
\hline \multirow{3}{*}{$\begin{array}{l}\text { Titre } \\
\text { IU } / \mathrm{ml}\end{array}$} & \multicolumn{9}{|c|}{ Days after vaccination } \\
\hline & \multicolumn{3}{|c|}{0} & \multicolumn{3}{|c|}{$30-40$} & \multicolumn{3}{|c|}{$350-370$} \\
\hline & Total & $\mathbf{R}$ & $\mathbf{M}$ & Total & $\mathbf{R}$ & $\mathbf{M}$ & Total & $\mathbf{R}$ & $\mathbf{M}$ \\
\hline$<0.5$ & $121^{\mathrm{a}}$ & 74 & 47 & 4 & 3 & 1 & 18 & 14 & 4 \\
\hline 0.5 & 4 & 4 & 0 & 1 & 1 & 0 & 21 & 13 & 8 \\
\hline $1.5-13.5$ & 0 & 0 & 0 & 59 & 38 & 21 & 62 & 37 & 25 \\
\hline$>13.5-81$ & 0 & 0 & 0 & 36 & 23 & 13 & 4 & 3 & 1 \\
\hline$>81$ & 0 & 0 & 0 & 30 & 18 & 12 & 1 & 1 & 0 \\
\hline GMT-IU/ml & 0.03 & 0.02 & 0.03 & 17.40 & $17.03^{b}$ & $18.05^{b}$ & 1.03 & $0.91^{\mathrm{c}}$ & $1.28^{\mathrm{c}}$ \\
\hline Sample size & 125 & 78 & 47 & 130 & 83 & 47 & 106 & 68 & 38 \\
\hline
\end{tabular}

$\mathbf{R}=$ Rabisin. $\mathbf{M}=$ Madivak.

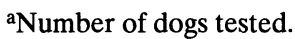

No significant difference in antibody level between dogs vaccinated with Rabisin or Madivak ${ }^{b} \mathrm{p}=0.8400 ;{ }^{\mathrm{c}} \mathrm{p}=0.3617$.

ence of neutralizing antibodies. Neutralizing antibody produced in response to vaccination is an important factor in the protection against rabies infection (Turner 1973, Turner 1978). The best relation between antibody production and protection has consistently been obtained with inactivated virus vaccines (Aubert 1993). For human pre-exposure immunization, it is recommended that antibody titres equivalent to at least $0.5 \mathrm{IU} / \mathrm{ml}$ be obtained (Anon. 1984). This same titre is also considered a good figure for canine immunization (Sage et al. 1993). Sweden and Norway, which have been free of rabies for a long time, have recently decided that vaccinated dogs may be brought into these countries if they have a rabies neutralizing titre of $\geq 0.5$ $\mathrm{IU} / \mathrm{ml} 4$ months after the first vaccination.

Results from Thailand (Tesumethanon et al. 1991) and Alaska (Sage et al. 1993) showed that a significant group of dogs did not produce a lasting antibody titre after 1 injection with inactivated tissue culture vaccine (Rabdomun). In Thailand, 6 out of 50 (12\%), 11 out of $43(25.6 \%)$ and 13 out of 31 (42\%) dogs had no detectable rabies antibody titre in serum 60,180 and 360 days, respectively, after vaccination. In Alaska, titres were less than $0.5 \mathrm{IU} / \mathrm{ml}$ in 7 out of $26(27 \%), 6$ out of 25 (24\%) and 7 out of 21 (33\%) dogs 60, 180 and 360 days, respectively, after vaccination. In our study, titres were less than $0.5 \mathrm{IU} / \mathrm{ml}$ in 4 out of $130(3.1 \%)$ and 18 out of $106(17 \%)$ dogs 30-40 and 350-370 days after vaccination. The percentage of dogs without antibody within 1 year of a single vaccination was smaller in our studies than in those mentioned above. Responses to the 2 rabies vaccines we used (Madivak and Rabisin) did not differ significantly. Our earlier studies in cattle showed a larger group of nonresponders $(20 \%)$ and animals without lasting antibody titre (58\%) than did dogs after a single vaccination (Sihvonen et al. 1994)

The 4 dogs which had an antibody titre of 0.5 $\mathrm{IU} / \mathrm{ml}$ at the time of vaccination were older than 1 year and, according to the owner, had not previously been vaccinated against rabies. We cannot, however, rule out the possibility that the dogs ( 2 of which were hunting dogs) 
might have received a rabies vaccination at some point. All 4 dogs had high antibody titres 1 month after vaccination. The RFFIT test measures the ability of a specific antibody to inhibit challenge viral growth in a cell culture. The presence in a serum sample of any non-specific (i.e., non-antibody) factors that interfere with cell or viral growth may have resulted in false positive reactions. The presence of rabies neutralizing antibodies in nonvaccinated animals has been reported in several papers (Campbell \& Barton 1988, Aubert 1993, Sihvonen et al. 1993). In our earlier studies on cattle, we did not find any non-specific reactions in 161 sera of non-vaccinated cattle (Sihvonen et al. 1994).

Our results show that a single vaccination with 1 dose of inactivated rabies vaccine of tissue culture origin induced moderate, but short-term, seroconversion in $96.9 \%$ of healthy, owned dogs. In $17 \%$ of the dogs, the antibody titres did not last for a whole year. Responses to rabies vaccine may vary considerably between dogs. Genetic and enviromental factors, immunosuppression and stress influence the immune response of vaccination. A booster is thus always necessary after a single injection to ensure that all dogs have a lasting antibody titre.

\section{Acknowledgements}

We thank veterinary surgeons Jaana Husu, Laura Kulkas, Auli Marttinen, Raili Schildt and Antti Sukura for vaccinating the dogs and taking the blood samples.

\section{References}

Anonymous: WHO Expert Committee on Rabies. Seventh Report, WHO Technical Report Series 709, WHO, Geneva, 1984.

Aubert MFA: Can vaccination validated by the titration of rabies antibodies in serum of cats and dogs be an alternative to quarantine measures? Abstracts on Hygiene and Communicable Disease, 1993, 68, 6, R2-R22.

Nyberg M, Kulonen K, Neuvonen E, Ek-Kommonen $C$, Nuorgam M, Westerling B: An epidemic of sylvatic rabies in Finland - Descriptive epidemiology and results of oral vaccination. Acta vet. scand. 1992, 33, 43-57.

Sage $G$, Khawplod P, Wilde H, Lobaugh $C$, Hemachwdha T, Tepaumethanon $W$, Lumlertdaecha $B$ : Immune response to rabies vaccine in Alaskan dogs: failure to achieve a consistently protective antibody response. Transations of the Royal Society of Tropical Medicine and Hygiene, 1993, 87, 593-595.

Sihvonen L, Kulonen K, Soveri T, Nieminen M: Rabies antibody titres in vaccinated reindeer. Acta vet. scand. 1993, 34, 199-202.

Sihvonen L, Kulonen K, Neuvonen E: Immunization of cattle against rabies using inactivated cell culture vaccines. Acta vet. scand. 1994, 35, 4, in press.

Smith JS, Yaeger PA, Baer GM: A rapid reproducible test for determing rabies neutralizing antibody. Bull. WHO. 1973, 48, 535-541.

Tepsumethanon W, Polsuwan C, Lumlertdaecha B, Khawplod P, Hemachudha T, Chutivongse S, Wilde H, Chiewbamrungkiat M, Phanuphak $P$ : Immune Response to rabies vaccine in Thai dogs: A preliminary report. Vaccine, 1991, 9, 627-630.

Turner GS: Humoral and cellural immune responses of mice to rabies and smallpox vaccines. Nature New Biol. 1973, 241, 90-92.

Turner GS: Immunoglobulin (IgG) and (IgM) antibody response to rabies vaccine. J. gen. Virol. 1978, 40, 595-604.

Wiktor TJ, MacFarlan RI, Foggin CM, Koprowski $H$ : Antigenic analysis of rabies and Mokola virus from Zimbabwe using monoclonal antibodies. Dev. Biol. Stand. 1984, 57, 199- 211.

\section{Sammanfattning}

Rabiesantikroppar hos vaccinerade hundar.

Fyrtiosju friska, ägda hundar vaccinerades med Madivak och 85 med Rabisin. De genom RFFIT erhållna mediantitren (GMT) 30-40 och 350-370 dygn efter primärvaccination var 17.40 respektive 1.03 $\mathrm{IU} / \mathrm{ml}$. Titer mindre än $0.5 \mathrm{IU} / \mathrm{ml}$ påvisades hos 4 av 
$130(3.1 \%)$ och 18 av $106(16 \%)$ hundar 30-40 respektive 350-370 dygn efter vaccination. Titern 0.5 IU/ml påvisades hos 21 hundar (19.8\%) 350-370 dygn efter vaccinationen. Ingen signifikant skillnad i antikropps-nivå kunde påvisas mellan hundar vaccinerade med Rabisin respektive Madivak. Våra re- sultat ger vid handen, att booster alltid är nödvändig efter primärvaccination för att alla hundar skall få bestående antikropps-titer. En antikropps-titer på $\geq 0.5 \mathrm{IU} / \mathrm{ml}$ kunde betraktas som det enklaste kriteriet på sannolikhet av att hunden inte skall insjukna i rabies efter eventuell exposition.

(Received June 6, 1994; accepted November 29, 1994).

Reprints may be requested from: L. Sihvonen, National Veterinary and Food Research Institute, Vaccine and Production and Virology Unit, P.O. Box 368, SF-00231 Helsinki, Finland. 
